DRGANIA WLASNE PRĘTÓW WSPORNIKOWYCH O KSZTALCIE PELNYCH I DRĄŻONYCH BRYL OBROTOWYCH

\title{
ВЛАСНІ КОЛИВАННЯ КОНСОЛЬНИХ СУЦЛЬНИХ СТЕРЖНІВ І ПУСТОТІЛИХ ТІЛ ОБЕРТАННЯ
}

\section{FREE VIBRATION OF CANTILEVERS - HOLLOW OR MASSIVE TWO- PART SOLIDS OF REVOLUTION}

Chalecki, M., dr inż., adiunkt, 0000-0003-3451-458X, Jaworski, J., dr inż., starszy wykładowca, Szlachetka, O., dr inż., adiunkt, 0000-0002-1195-3603, Bagdasaryan, V., dr inż., adiunkt 0000-0002-9589-1453 (Szkoła Główna Gospodarstwa Wiejskiego w Warszawie - SGGW)

Халецьки М., канд. техн. наук, доцент, 0000-0003-3451-458Х, Яворськи Я., канд. техн. наук, старший викладач, Шляхетка О., канд. техн. наук, доцент, 0000-0002-1195-3603, Багдасарян В., канд. техн. наук, доцент 0000-0002-9589-1453 (Варшавський університет наук про життя - SGGW)

Chalecki, M., Ph.D., assistant professor, 0000-0003-3451-458X, Jaworski, J., Ph.D., senior lecturer, Szlachetka, O., Ph.D., assistant professor, 0000-00021195-3603, Bagdasaryan, V., Ph.D., assistant professor 0000-0002-9589-1453 (Warsaw University of Life Sciences - SGGW, )

W pracy obliczono częstości drgań własnych słupów o zmiennym przekroju poprzecznym z wykorzystaniem metody Rayleigh'a. Słupy składają się z dwóch części, każda ma ksztalt pełnego lub drążonego krzywo- lub prostoliniowego stożka ściętego. Obliczenia wykonano w środowiskach MATHEMATICA i ANSYS; wyniki są bardzo zbliżone do siebie.

В роботі, при використанні методу Релея, вирахувано частоти власних коливань колон змінного поперечного перерізу. Колони складені 3 двох частин, кожна $з$ яких має вигляд суцільного або пустотілого нелінійного чи прямолінійного зрізаного конуса. Розрахунки виконано в середовищі MATHEMATICA i ANSYS. Вказано на суттєве співпадіння отриманих результатів.

The Rayleigh's method can be used to determine the first natural frequency of bars (beams or posts) with variable cross-section. The authors analyze slender cantilever bars - solids of revolution, made of an elastic material. The bars consist of two parts, each having the shape of massive or hollow curvilinear 
truncated cone, with the internal and external generatrices being a straight line or curve (parabola, exponential line). It has been assumed that the neutral bar axis deflected during vibrations has a shape of a beam deflected by a static uniform load. The calculations were made in MATHEMATICA environment and their results are very close to those obtained with FEM.

Słowa kluczowe: pręt wspornikowy o zmiennym przekroju, pierwsza częstość drgań własnych, metoda Rayleigh’a

консольний стержень змінного поперечного перерізу, перша частота власних коливань, метод Релея

cantilever bar with variable cross section, first natural frequency, Rayleigh's method

\section{Wstęp.}

Dla wielu konstrukcji wspornikowych (słupy, wieże, kominy) należy sprawdzić ich podatność na dynamiczne wpływy porywów wiatru. Dlatego dobrze jest mieć możliwość przybliżonego obliczenia wartości pierwszej częstości poprzecznych drgań własnych elementów prętowych o zmiennym przekroju i różnych kształtach. Aby to osiągnąć, stosuje się różne metody - np. całkowanie równania różniczkowego osi ugiętej belki Bernoulliego-Eulera. Dokładne rozwiązania są tu jednak znane tylko dla szczególnych przypadków. Jednym z nich jest wzorcowe rozwiązanie dla pręta $\mathrm{w}$ kształcie klina i stożka ściętego [1], otrzymane w postaci funkcji Bessela, które do obliczeń numerycznych zostały zastapione wielomianami równoważnymi. Caruntu [2] przedstawił rozwiązanie dla pręta w kształcie bryły obrotowej o krzywoliniowych (parabolicznych) tworzących i z ostrym końcem swobodnym. Inni autorzy $[3,4,5]$ również analizowali problem pręta w kształcie stożka ściętego, wykorzystując różne metody. Niektóre badania dotyczyły prętów o prostokątnym przekroju poprzecznym, gdzie jeden $\mathrm{z}$ wymiarów tego przekroju był stały, a drugi zmieniał się według funkcji liniowej [6], kwadratowej [2] albo ekspotencjalnej [7]. Analizując pręty o przekroju poprzecznym zmiennym w sposób ciągły, wielu autorów [8, 9] zastępowało je prętami o przekroju zmieniającym się w sposób dyskretny Jednakże w literaturze nie istnieją wzorcowe rozwiązania dla prętów drążonych o złożonych kształtach.

Metoda Rayleigh'a okazała się przydatna do określenia pierwszej częstości poprzecznych drgań własnych prętów o kształcie tak pełnego, jak i drążonego stożka ściętego, z tworzącymi w postaci linii prostej albo paraboli wklęsłej [10] lub wypukłej [11] względem wzdłużnej osi stożka. Porównanie energii kinetycznej i potencjalnej przy założeniu, że kształt osi obojętnej pręta uginającego się pod wpływem drgań jest taki sam, jak kształt osi obojętnej pręta uginającego się pod wpływem obciążenia statycznego o stałej wartości rozłożonego w sposób ciągły, umożliwia określenie pierwszej częstości drgań własnych z dokładnością dostateczną dla obliczeń inżynierskich.

Autorzy niniejszej pracy wykorzystali metodę Rayleigh'a do określenia pierwszej częstości drgań własnych pełnych i drążonych, dwuczęściowych prętów 
wspornikowych. Pręt o zmiennym przekroju poprzecznym podzielono na elementy o stałych średnicach (wewnętrznych i zewnętrznych). Założono, że amplituda drgań jest mała, materiał pręta jest jednorodny, izotropowy i idealnie sprężysty, pręty są smukłe, a ich masa jest rozłożona w sposób ciągły. Do przeprowadzenia obliczeń autorzy wykorzystali środowisko MATHEMATICA. Otrzymane w taki sposób wyniki porównano $\mathrm{z}$ wynikami uzyskanymi $\mathrm{W}$ metodzie elementów skończonych (MES).

\section{Metodyka}

Rozpatrzono słup - pręt wspornikowy w kształcie bryły obrotowej, jak na rys. 1, podzielony na dwie części, których tworzące (wewnętrzna i zewnętrzna) są opisane różnymi funkcjami - liniową, paraboliczną lub ekspotencjalną. Każda funkcja jest zależnością od średnicy pręta - zewnętrznej $\Delta^{(j)}(x)$ albo wewnętrznej $\delta^{(j)}(x)-\mathrm{w}$ dowolnym przekroju poprzecznym na współrzędnej $x$ położenia tego przekroju ( $j=1,2$ - numer części). Pole przekroju poprzecznego i jego moment bezwładności są równe odpowiednio:

$$
A^{(j)}(x)=\frac{\pi\left[\left(\Delta^{(j)}\right)^{2}(x)-\left(\delta^{(j)}\right)^{2}(x)\right]}{4}, J^{(j)}(x)=\frac{\pi\left[\left(\Delta^{(j)}\right)^{4}(x)-\left(\delta^{(j)}\right)^{4}(x)\right]}{64}
$$

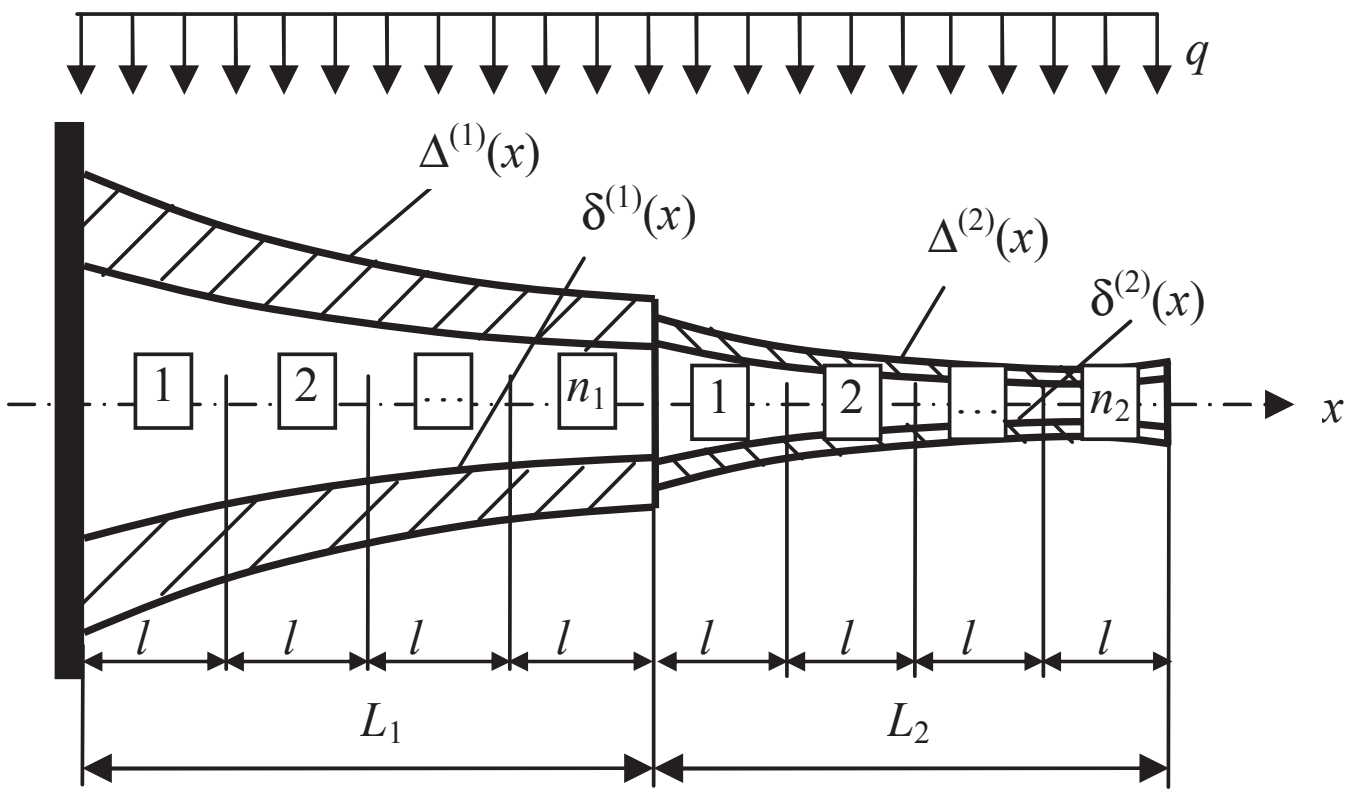

Rys. 1. Ogólny kształt pręta równomiernie obciążonego

Ugięcie pręta pod wpływem stałego obciążenia ciągłego oblicza się poprzez całkowanie równania różniczkowego sprężystej osi belki:

$$
E J(x) \frac{d^{2} u(x)}{d x^{2}}=-M_{b}(x),
$$

gdzie $u(x)$ - ugięcie, $E$ - moduł Younga, $M_{b}$ - moment gnący w przekroju określonym współrzędną $x$. 
Założenie, że oś obojętna pręta uginającego się pod wpływem drgań ma kształt opisany funkcją $u(x)$, umożliwia obliczenie energii potencjalnej $\mathrm{w}$ położeniu maksymalnego ugięcia i energię kinetyczną $\mathrm{w}$ położeniu równowagi. Energia potencjalna $\left(E_{p}\right)$ i kinetyczna $\left(E_{k}\right)$ są równe odpowiednio:

$$
E_{p}=\int_{0}^{L} \frac{1}{2} q u(x) d x, \quad E_{k}=\int_{0}^{L} \frac{1}{2} \rho A(x) \omega^{2} u^{2}(x) d x,
$$

gdzie $\rho$ - gęstość masy, $\omega$ - częstość drgań własnych. Porównanie energii umożliwia określenie tej częstości.

Wyrażenia podcałkowe są bardzo złożone - tym bardziej, jeśli dotyczą drążonego pręta wspornikowego $[10,11]$. Dlatego całkowanie zastąpiono sumowaniem. W tym celu pierwszą i drugą część pręta podzielono odpowiednio na $n_{1}$ i $n_{2}$ elementów, przy czym każdy element ma stałą średnicę (wewnętrzną albo zewnętrzną - równą odpowiedniej średnicy w środku długości elementu) i taką samą długość $l=\frac{L_{1}}{n_{1}}=\frac{L_{2}}{n_{2}}$. Liczba składników w sumie (wielkości $n_{1}$ i $n_{2}$ ) stale rosła w kolejnych iteracjach. Jedna iteracja obejmuje wzory (4) $\div(12)$. Sumowanie dotyczy globalnych ugięć środków każdego elementu. Przyjmując ogólny kształt pręta pokazany na rys. $1, \mathrm{w}$ celu obliczenia tych ugięć należy wykonać następujące kroki (we wzorach (4) $\div(10) i_{1}, i_{2}-$ liczby całkowite, $i_{1} \in\left\langle 1, n_{1}\right\rangle, i_{2} \in\left\langle 1, n_{2}\right\rangle$ ): - obliczenie reakcji w lewym końcu każdego z elementów:

$$
R_{i_{1}}^{(1)}=q\left(L_{1} \frac{n_{1}-i+1}{n_{1}}+L_{2}\right), R_{i_{2}}^{(2)}=q L_{2} \frac{n_{2}-i+1}{n_{2}},
$$

- obliczenie momentów utwierdzenia w lewym końcu każdego z elementów:

$$
M_{i_{1}}^{(1)}=\frac{q}{2}\left(L_{1} \frac{n_{1}-i+1}{n_{1}}+L_{2}\right)^{2}, M_{i_{2}}^{(2)}=\frac{q}{2}\left(L_{2} \frac{n_{2}-i+1}{n_{2}}\right)^{2},
$$

- obliczenie ugięć prawych końców każdego z elementów we współrzędnych lokalnych:

$$
u_{i_{j}}^{(j)}=\frac{1}{E J^{(j)}}\left(\frac{1}{2} M_{i_{j}}^{(j)}\left(\frac{L_{j}}{n_{j}}\right)^{2}-\frac{1}{6} R_{i_{j}}^{(1)}\left(\frac{L_{j}}{n_{j}}\right)^{3}+\frac{1}{24} q\left(\frac{L_{j}}{n_{j}}\right)^{4}\right), j=1,2,
$$

- obliczenie ugięć środków każdego elementu we współrzędnych lokalnych:

$$
\hat{u}_{i_{j}}^{(j)}=\frac{1}{E J^{(j)}}\left(\frac{1}{2} M_{i_{j}}^{(j)}\left(\frac{L_{j}}{2 n_{j}}\right)^{2}-\frac{1}{6} R_{i_{j}}^{(1)}\left(\frac{L_{j}}{2 n_{j}}\right)^{3}+\frac{1}{24} q\left(\frac{L_{j}}{2 n_{j}}\right)^{4}\right), j=1,2,
$$

- obliczenie kątów obrotu prawych końców każdego elementu we współrzędnych lokalnych: 


$$
\varphi_{i_{j}}^{(j)}=\frac{1}{E J^{(j)}}\left(M_{i_{j}}^{(j)} \frac{L_{j}}{n_{j}}-\frac{1}{2} R_{i_{j}}^{(1)}\left(\frac{L_{j}}{n_{j}}\right)^{2}+\frac{1}{6} q\left(\frac{L_{j}}{n_{j}}\right)^{3}\right), j=1,2 .
$$

Ugięcia środków we współrzędnych globalnych są równe:

- dla pierwszej części:

$$
U_{i_{1}}^{(1)}=\sum_{k=1}^{i_{1}-1} u_{k}^{(1)}+\hat{u}_{k}^{(1)}+\sum_{k=1}^{i_{1}-1} \varphi_{k}^{(1)}\left(i_{1}-k-0,5\right) \frac{L_{1}}{n_{1}}
$$

- dla drugiej części:

$$
\begin{aligned}
U_{i_{2}}^{(2)}=\sum_{k=1}^{n_{1}} u_{k}^{(1)}+\sum_{k=1}^{n_{1}-1} \varphi_{k}^{(1)} & \left(n_{1}-k\right) \frac{L_{1}}{n_{1}}+\sum_{k=1}^{n_{1}-1} \varphi_{k}^{(1)}\left(i_{2}-0,5\right) \frac{L_{2}}{n_{2}}+\sum_{k=1}^{i_{2}-1} u_{k}^{(2)}+\hat{u}_{k}^{(2)}+ \\
& +\sum_{k=1}^{i_{2}-1} \varphi_{k}^{(2)}\left(i_{2}-k-0,5\right) \frac{L_{2}}{n_{2}}
\end{aligned}
$$

Otrzymawszy te ugięcia, całkowanie we wzorach (3) można zastąpić następującym sumowaniem:

$$
\begin{gathered}
E_{p}=\frac{q l}{2}\left[\sum_{k=1}^{n_{1}} U_{k}^{(1)}+\sum_{k=1}^{n_{2}} U_{k}^{(2)}\right], \\
E_{k}=\frac{\rho \omega^{2} l}{2}\left[\sum_{k=1}^{n_{1}} A_{k}^{(1)}\left(U_{k}^{(1)}\right)^{2}+\sum_{k=1}^{n_{2}} A_{k}^{(2)}\left(U_{k}^{(2)}\right)^{2}\right] .
\end{gathered}
$$

Porównanie tych energii, zgodnie z metodą Rayleigh'a, daje pierwszą częstość drgań własnych i okres drgań:

$$
T=\frac{2 \pi}{\omega}=2 \pi \sqrt{\frac{\rho}{E}} \sqrt{\left(\sum_{k=1}^{n_{1}} A_{k}^{(1)}\left(U_{k}^{(1)}\right)^{2}+\sum_{k=1}^{n_{2}} A_{k}^{(2)}\left(U_{k}^{(2)}\right)^{2}\right) /\left(\sum_{k=1}^{n_{1}} U_{k}^{(1)}+\sum_{k=1}^{n_{2}} U_{k}^{(2)}\right)}
$$

Takie iteracje należy przeprowadzać dotąd, aż różnica względna między wynikami $(T)$ dwóch ostatnich iteracji jest mniejsza niż pewna wielkość wybrana przez użytkownika (np. 0,001\%). Aby otrzymać największą dokładność, należy utrzymywać stałą długość $l$, zatem wielkości $n_{1}$ i $n_{2}$ powinny spełniać proporcję

$$
l=\frac{L_{1}}{n_{1}}=\frac{L_{2}}{n_{2}} .
$$

\section{Wyniki obliczeń}

Zaprezentowaną powyżej procedurę obliczeń częstości drgań własnych (dalej „procedurę") zastosowano dla tworzących opisanych trzema rodzajami linii, od których zależą wzory na $\Delta \mathrm{i} \delta$ :

- linia prosta 


$$
d^{(1)}(x)=d_{b}^{(1)}-\frac{d_{b}^{(1)}-d_{e}^{(1)}}{L_{1}} x, \quad d^{(2)}(x)=d_{b}^{(2)}-\frac{d_{b}^{(2)}-d_{e}^{(2)}}{L_{2}}\left(x-L_{2}\right) ;
$$

- parabola wklęsła

$$
d^{(1)}(x)=d_{b}^{(1)}\left(1-\left(1-\frac{d_{e}^{(1)}}{d_{b}^{(1)}}\right) \sqrt{\frac{x}{L_{1}}}\right), \quad d^{(2)}(x)=d_{b}^{(2)}\left(1-\left(1-\frac{d_{e}^{(2)}}{d_{b}^{(2)}}\right) \sqrt{\frac{x-L_{1}}{L_{2}}}\right)
$$

- eksponenta

$$
d^{(1)}(x)=d_{b}^{(1)}\left(\frac{d_{b}^{(1)}}{d_{e}^{(1)}}\right)^{-\frac{x}{L_{1}}}, \quad d^{(2)}(x)=d_{b}^{(2)}\left(\frac{d_{b}^{(2)}}{d_{e}^{(2)}}\right)^{-\frac{x-L_{1}}{L_{2}}} .
$$

gdzie: $d=\Delta$ dla średnic zewnętrznych, $d=\delta$ dla średnic wewnętrznych, $d_{b} / d_{e}-$ średnica w początkowym / końcowym przekroju pręta.

Autorzy przetestowali żelbetowe słupy wspornikowe $\left(\sqrt{\rho / E}=3,5 \cdot 10^{-4} \mathrm{~s} \cdot \mathrm{m}^{-1}\right)$ w kształcie pełnych albo drążonych dwuczęściowych brył obrotowych o tworzacych prosto- lub krzywoliniowych; pokazano je na rys. 2. Wyniki procedury porównano z wynikami otrzymanymi z użyciem MES (ANSYS - tab. 1). Aby to uzyskać, tworzące krzywoliniowe przybliżono 16 krótkimi odcinkami prostymi, potem przy wykorzystaniu elementów SOLID utworzono siatkę regularną HEXA. Wysokość słupa podzielono na 192 elementy (12 na jeden odcinek), obwód - na 40 elementów (9 stopni na jeden odcinek), grubość ścianki słupa - na 4 elementy: w ten sposób powstała siatka zawierająca ok. 30000 elementów. Zgodnie z tab. 1, częstości obliczone w MES są nieco niższe niż obliczone w procedurze - różnica jest rzędu $1 \div 3 \%$.

Największa różnica $\Delta$ dotyczy słupa drążonego z opaską u głowicy. Taka opaska zwiększa wpływ obrotowego momentu bezwładności, który nie jest uwzględniony w procedurze, ale uwzględnia się go w programach MES. Wpływ opaski u głowicy na dokładność wyników będzie tym większy, im wyżej (bliżej swobodnego końca) będzie opaska, im wyższy będzie moment bezwładności jej przekroju poprzecznego (np. większa średnica zewnętrzna) i im mniejszą sztywność będzie miał słup u podstawy (np. będzie drążony albo cienkościenny). 


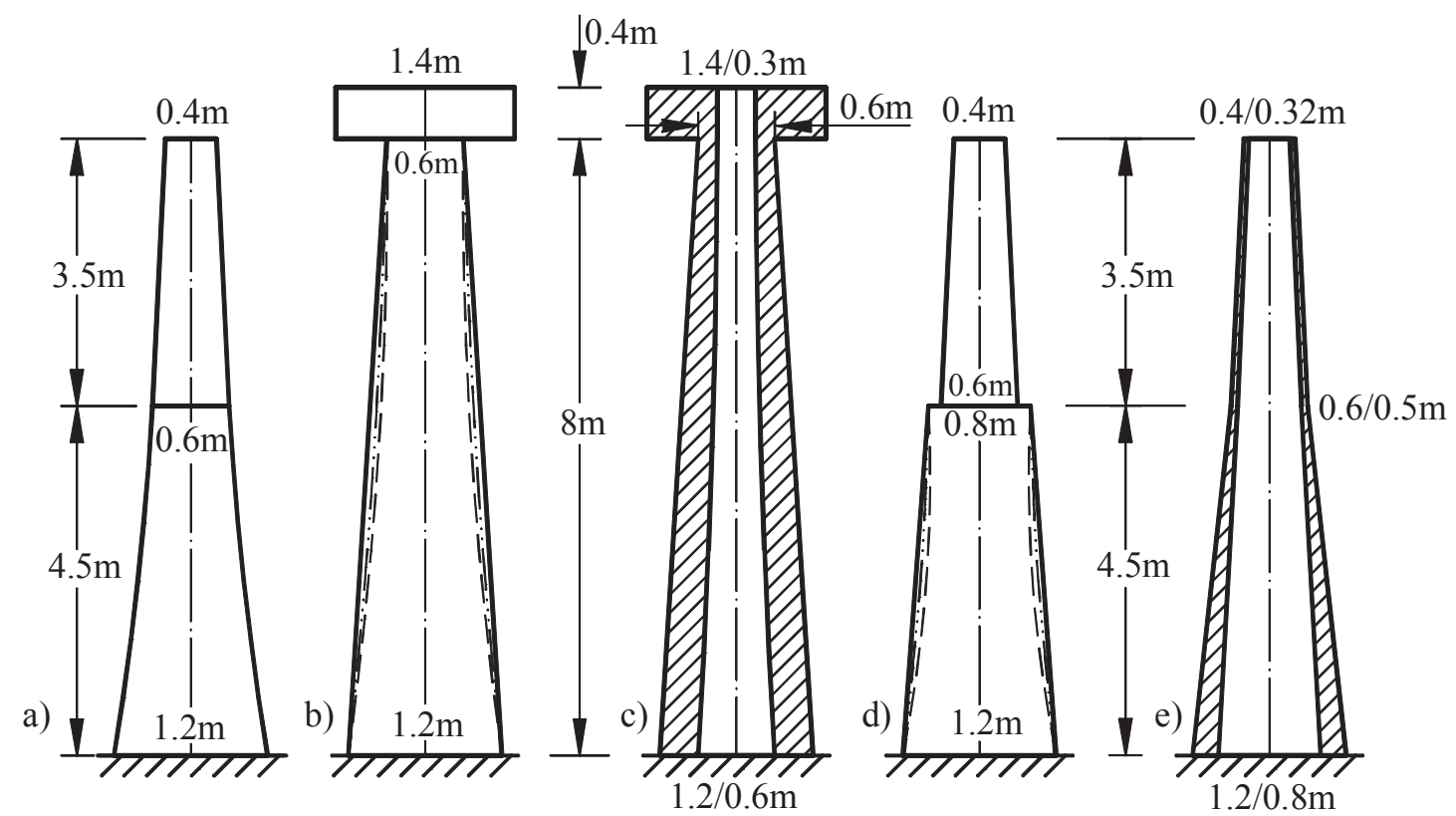

Rys. 2. Ksz b)ty prętów: a) doln c):zęść - tworz d)a paraboliczna, ६e)'na część prostoliniowa; b) tworzące: prostoliniowa $\left(b_{1}\right)$, paraboliczna $\left(b_{2}\right)$, ekspotencjalna $\left.\left(b_{3}\right) ; \mathrm{c}\right)$ tworząca wewnętrzna - ekspotencjalna, tworząca zewnętrzna - prostoliniowa; d) dolna część - tworzące: prostoliniowa $\left(d_{1}\right)$, paraboliczna $\left(d_{2}\right)$, ekspotencjalna $\left(d_{3}\right)$, górna część prostoliniowa; e) wszystkie tworzące prostoliniowe

Tab. 1.

Porównanie częstości drgań własnych obliczonych z wykorzystaniem procedury i MES

\begin{tabular}{|c|c|c|c|c|c|c|c|c|c|}
\hline słup & $a$ & $b_{1}$ & $b_{2}$ & $b_{3}$ & $c$ & $d_{1}$ & $d_{2}$ & $d_{3}$ & $e$ \\
\hline $\begin{array}{c}\mathrm{f}[\mathrm{Hz}]- \\
\text { autorzy }\end{array}$ & 8.620 & 7.044 & 5.587 & 6.645 & 7.415 & 12.20 & 10.84 & 11.96 & 14.73 \\
\hline $\begin{array}{c}\mathrm{f}[\mathrm{Hz}]- \\
\mathrm{MES}\end{array}$ & 8.557 & 6.891 & 5.478 & 6.478 & 7.192 & 11.97 & 10.72 & 11.73 & 14.44 \\
\hline$\Delta[\%]$ & 0.74 & 2.22 & 1.99 & 2.58 & 3.10 & 1.92 & 1.12 & 1.96 & 2.01 \\
\hline
\end{tabular}

Wnioski. W pracy przedstawiono pewną procedurę obliczania pierwszej częstości drgań własnych pełnych i drążonych, dwuczęściowych brył obrotowych o zmiennych przekrojach poprzecznych. Dokładność tej procedury jest dostateczna do obliczeń inżynierskich. Procedurę można z powodzeniem rozszerzyć na pręty wieloczęściowe. Oprócz tego, umożliwia ona uwzględnienie mas punktowych. Opaski nałożone na powierzchnie boczne konstrukcji powłokowych (kominów stalowych, wież żelbetowych) czasami są modelowane właśnie takimi masami punktowymi - w przedstawionej procedurze taką masę można uwzględnić, zmieniając średnicę jednej z części, jak na rys. 2b, c.

Metoda jest dość prosta, ale dokładna, co można uznać za jej największą zaletę. Różnice między wynikami otrzymanymi w MES i $\mathrm{z}$ użyciem 
przedstawionej procedury nie przekraczają 3,1\%, co można uznać za umiarkowaną wielkość (dla kominów bez opasek nie przekracza ona 2\%).

1. Conway, H. D. Vibration frequencies of truncated-cone and wedge beams / Conway, H. D. and Dubil, J. F. // Journal of Applied Mechanics - 1965 - 32 (4) - pp. 932-934.

2. Caruntu, D. I. Dynamic modal characteristics of transverse vibrations of cantilevers of parabolic thickness / Caruntu, D. I. // Mechanics Research Communications - 2009 - 36 (3) - pp. 391-404.

3. Abdelghany, S.M. Vibration of a circular beam with variable cross sections using differential transformation method / Abdelghany, S.M., Ewis, K.M., Mahmoud, A.A., Nassar, M.M. // Beni-Suef Univ. J. Basic Appl. Sci. - 2007 - 4 (3) - pp. 185-191.

4. Coşkun, S.B. Transverse vibration analysis of Euler-Bernoulli beams using analytical approximate techniques / Coşkun, S.B., Atay, M.T., Öztürk, B. // INTECH Open Access Publisher - 2011.

5. Naguleswaran, S. A direct solution for the transverse vibration of Euler-Bernoulli wedge and cone beams / Naguleswaran, S. // Journal of Sound and Vibration - 1994 172(3) - pp. 289-304.

6. Datta, A. K. An analysis of free undamped vibration of beams of varying cross section / Datta, A. K., \& Sil, S. N // Computers \& structures - 1996 - 59(3) - pp. 479-483.

7. Ece, M. C. Vibration of variable cross-section beam / Ece, M. C., Aydogdu, M. and Taskin, V. // Mechanics Research Communications - 2007 - 34 (1) - pp. 78-84.

8. Torabi, K. Vibration Analysis of Multi-Step Bernoulli-Euler and Timoshenko Beams Carrying Concentrated Masses / Torabi, K., Afshari, H., Najafi H. // Journal of Solid Mechanics - 2013 - 5(4) - pp. 336-349.

9. Wu, J.-S. Free vibrations of solid and hollow wedge beams with rectangular or circular cross-sections and carrying any number of point masses / Wu, J.-S. and Chiang, L.K. // International Journal for Numerical Methods in Engineering - $2004-60-$ pp. 695718.

10. Jaworski, J. Free vibrations of cantilever bars with linear and nonlinear variable cross-section / Jaworski, J. and Szlachetka, O. // Discontinuity, Nonlinearity, and Complexity - $2017-6(4)-$ pp. 513-521.

11. Szlachetka, O. Analysis of free vibrations of cantilever bars with parabolically variable cross-sections using the Rayleigh's method / Szlachetka, O., Jaworski, J., Chalecki, M. // Acta Scientiarum Polonorum Architectura - 2017 - 16 (4) - pp. 5-14. 